\title{
A familial risk profile for osteoporosis
}

\author{
L.B. Henderson, $M D^{1,2}$, J.S. Adams, $M D^{1,3}$, D.R. Goldstein, PhD', G.D. Braunstein, $M D^{1,3}$, J.I. Rotter, $M D^{1,2}$, and
} M.T. Scheuner, $M D, M P H^{1,2}$

\begin{abstract}
Purpose: To describe genetic epidemiologic aspects of osteoporosis. Methods: 69 patients with osteoporosis were interviewed regarding personal and family histories of osteoporosis and related fractures. Family history information was obtained on 421 first degree and 748 second degree relatives. Results: $45 \%$ of cases reported a family history of osteoporosis. Familial cases were characterized neither by an earlier age of diagnosis nor by a greater degree of phenotypic severity. Empiric risks for osteoporosis were highest for mothers, 33\%, and were 19\% for sisters. Conclusion: These results provide an initial genetic epidemiologic profile for osteoporosis and information useful for genetic counseling. Genetics in Medicine, 2000:2(4):222-225.
\end{abstract}

Key Words: genetic epidemiology, osteoporosis, family history, genetic counseling, empiric risk

Though a major public health concern, prevalence data for osteoporosis are imprecise as there exists an assortment of phenotypic and diagnostic assessment strategies. An estimated 16.8 million ( $54 \%$ ) postmenopausal Caucasian women in the United States have low bone mineral density, and an additional 9.4 million (30\%) are thought to have osteoporosis. ${ }^{1}$ Osteoporosis is the underlying etiology for more than one million total fractures and 50,000 deaths per year, and it accounts for an estimated 10-14 billion dollars in annual health care expenditures. ${ }^{2-4}$

Historically, osteoporosis has been described as a clinical syndrome characterized by skeletal deformation, pain, and fracture in susceptible individuals with decreased bone mineral density (BMD). Deformation often results from fractures of predominantly trabecular bone including, but not limited to, the femoral neck, distal radius, ribs, or vertebrae. ${ }^{5-7}$ Vertebral crush fractures often lead to a loss of height and a exaggeration of the thoracic kyphosis. ${ }^{8}$ The advent of dual energy $\mathrm{x}$-ray absorptiometry (DEXA) has heralded the evolution of diagnostic criteria. The World Health Organization (WHO) criteria state that individuals whose BMD is between 1.0 and 2.5 standard deviations below an idealized young adult mean have osteopenia, and those whose BMD is 2.5 standard deviations or more below such a mean are now classified as having osteoporosis. ${ }^{9,10} \mathrm{z}$-Scores are the corresponding analogous values given to patients for each anatomic site studied. For instance, a patient given a right femoral neck $z$-score of -2.5 has BMD at

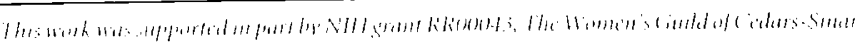

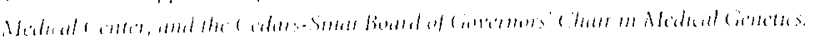

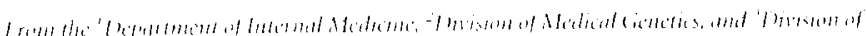

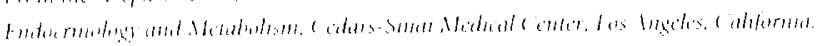

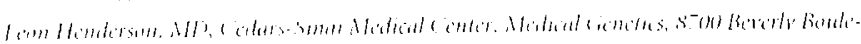

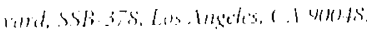

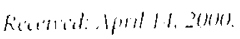

Areptiot: Mur 19. 2(m)
}

that site 2.5 standard deviations below the idealized young adult mean.

Among the metabolic risk factors known to contribute to the development of osteoporosis are estrogen deficiency, corticosteroid excess, hyperparathyroidism, hyperthyroidism, prolonged immobility, prolonged dietary calcium deficiency, hypercalciuric states, hypovitaminosis $\mathrm{D}$, and low peak bone mass. ${ }^{4,11-17}$ Tobacco smoking and alcohol use are also known risk factors. ${ }^{15,16,18}$

Evidence for a genetic contribution to the disorder derives from several types of investigations. Ethnic differences in frequency are recognized with Caucasian and Asian individuals at a significantly greater risk for the condition compared to their Hispanic and African American counterparts. ${ }^{19,20}$ The On-line Mendelian Inheritance in Man database ${ }^{21}$ records more than 70 genetic syndromes inherited in a mendelian fashion that feature osteoporosis. 22 The presence of mendelian varieties of a condition suggests that at least a subset of the "garden variety" condition has genetic underpinnings. A greater correlation for BMD among family members exists when compared with controls. ${ }^{22.23}$ In a prospective study following white women of mean age 72 years, a maternal history of hip fracture doubled the risk of an initial hip fracture during a 4.1 year average follow-up period. ${ }^{24}$ Both twin studies and population association studies have made more definitive the evidence of a genetic etiology for osteoporosis. Several twin studies have demonstrated a greater concordance rate of BMD among monozygotic twin pairs when compared with dizygotic twin pair counterparts. ${ }^{25-28}$ Furthermore, the heritability of the trait of peak bone mass, a trait that is inversely correlated with the likelihood for the development of osteoporosis, has been estimated to be as much as $90 \%$ in the lumbar spine and $70 \%$ at the femoral neck. $22,23,25,29$

There is evidence for and against population associations between BMD and Vitamin D receptor polymorphisms. The $\mathrm{BB}$ genotype was found predictive of low BMD or fracture in several studies, ${ }^{30-33}$ but in other studies ${ }^{34-38}$ not only is this 
genotype not predictive of low BMD, but also it fails to predict fracture. The CollAl Sp polymorphism may be an important marker for low bone mass and vertebral fracture, ${ }^{39}$ and some families exist in which individuals with "idiopathic" osteoporosis are more likely to have specific mutations in the CollAl or Col1 A2 gene. .00,41 $^{2}$

Although a "positive family history" has been long touted as a factor contributing to the risk of the development of osteoporosis, and despite a vast array of literature suggesting that osteoporosis is a disorder with a major genetic influence and appreciable heritability, sufficiently refined empiric risk estimates for meaningful genetic counseling is, to our knowledge, lacking in the medical literature. Moreover, it is not known the degree to which familial cases differ from nonfamilial cases. Genetic epidemiologic data including empiric risk estimates may be used in conjunction with other clinical data to establish a risk profile to facilitate, in an asymptomatic individual, the development of appropriate preventive strategies and anticipatory care. In osteoporosis, such data may be used in concert with radiographic and clinical data to assess the need for therapies designed to favorably impact a consultant's BMD. Estrogen, calcium, and vitamin D supplementation has been used toward this clinical goal as has weight-bearing exercise, smoking cessation programs, and osteoclast-stabilizing pharmacologic agents.

Thus we sought to refine our knowledge of the genetic epidemiologic aspects of osteoporosis in the Caucasian population. Our aims were ( 1 ) to assess the differences between familial and nonfamilial cases, and (2) to estimate gender and relative-specific empiric risks for first and second degree family members.

\section{MATERIALS AND METHODS}

The study subjects were ascertained from two clinical endocrinology practices at Cedars-Sinai Medical Center. Institutional Review Board approval was obtained. Charts were reviewed in order to identify those with the diagnosis of osteoporosis as defined by reduced bone mineral density (ascertained by DEXA) or clinical criteria. All measurements were performed by DEXA on a QDR-2000 (Hologic, Inc., Waltham, MA) or a DPX-L densitometer (Lunar Corp., Madison, WI). Individuals with BMD greater than or equal to 2.5 standard deviations below an idealized young adult mean, by DEXA, were considered to have osteoporosis. Those with BMD between 1 and 2.5 SD below such a mean were also considered to have osteoporosis if they had a history of low trauma fracture or evidence of compromised bone tissue such as loss of height or an exaggerated thoracic kyphosis. All affected individuals had a documented history of osteoporosis in their clinical chart. Subjects were excluded if they had hyperparathyroidism, ${ }^{25}$ hyperthyroidism, ${ }^{12}$ used steroids for six months or longer, ${ }^{4,12}$ had abnormal 25 -hydroxy vitamin D levels, ${ }^{10}$ or were unable to participate in the phone interview (12). The charts of each proband were reviewed in order to obtain relevant data from their most recent DEXA scan.
A standardized phone questionnaire was administered. Standard demographics, age of osteoporosis diagnosis, history of osteoporotic fractures, and family history regarding all first and second degree relatives were obtained from each subject. Family histories included age or age at death, cause of death, history of osteoporosis and related fractures, and the ages of diagnosis for these conditions. A family history of osteoporosis was considered when there was a report of at least one first degree relative with either a diagnosis of osteoporosis or a related fracture of the neck, back, rib, wrist, or hip at an age greater than or equal to 50 .

Descriptive statistics were used to estimate empiric risks. The chi-square test of homogeneity for proportions and t-test for differences between means were used to assess statistical significance of differences between compared values.

\section{RESULTS}

Data were collected from 69 patients; $97 \%$ were Caucasian, and $83 \%$ were female. Their mean age was 62 years (range: $36-86$ ), and their mean age of osteoporosis diagnosis was 57 years (range: $29-80$ ) for females, and 62 years $(49-81)$ for males. Mean z-scores at the lumbar spine were $-2.56( \pm 1.08)$ for females and $-1.62( \pm 2.00)$ for males. The mean $z$-scores at the right femoral neck were $-2.43( \pm 0.91)$ for females and $-2.53( \pm 1.48)$ for males. $20 \%$ of cases reported osteoporosisrelated fractures. Family history data were obtained regarding 421 first degree relatives and 748 second degree relatives. The percentage of first degree relatives reported to have a diagnosis of osteoporosis was greater than the proportion of second degree relatives reported to have the diagnosis $(8.0 \%$ vs. $3.7 \%$, respectively, $P=0.008$ ). Among all relatives, the first degree relatives did not differ significantly (at the $P=0.05$ level) from the second degree relatives with respect to proportion female, mean age at osteoporosis diagnosis, and proportion with an osteoporosis-related fracture.

Forty-five percent of the probands reported a family history of osteoporosis. Overall, the 57 females and 12 males did not differ significantly with regard to their age, age at diagnosis of osteoporosis, percentage with osteoporosis related fracture, and percentage with a family history of osteoporosis (Table 1). The 31 familial cases were virtually identical to the 38 nonfamilial cases with respect to mean age, mean age of osteoporosis diagnosis, proportion of females, proportion with a history of an osteoporosis-related fracture, mean pedigree size, BMD at the lumbar spine, and BMD at the right femoral neck (Table 2).

Twenty-three mothers either had the diagnosis of osteoporosis or an osteoporosis-related fracture. Thus, the empiric risk for mothers was $23 / 69 \times 100 \%$ or $33 \%$. Likewise, as 4 of $69 \mathrm{fa}-$ thers were affected, the empiric risk for fathers was $6 \%$. Sisters and brothers had empiric risks of $19 \%$ and $3 \%$, respectively. Grandmothers and aunts had a $6 \%$ risk, whereas grandfathers and uncles had a $1 \%$ risk. The female to male risk ratio ranged from 4.7 for siblings to 6.0 for both grandparents and avuncular relatives. The female to male risk ratio for parents was 5.5 (Table 3). 
Table 1

Proband characteristics $(n=69)$ *

\begin{tabular}{lrr}
\hline Parameter & Female $(\mathrm{n}=57)$ & Male $(\mathrm{n}=12)$ \\
\hline Mean age (range) & $62(36,85)$ & $66(52,86)$ \\
Mean age at diagnosis (range) & $57(29,80)$ & $62(49,81)$ \\
$\begin{array}{l}\text { Percent with fracture }>50 \\
\quad \text { years old }\end{array}$ & $20.0 \%(10 / 50)$ & $33.3 \%(4 / 12)$ \\
$\begin{array}{l}\text { Percent with family history of } \\
\quad \text { osteoporosis }\end{array}$ & $47 \%(27 / 57)$ & $33 \%(4 / 12)$ \\
Lumbar BMD z-score & $-2.56( \pm 1.08)$ & $-1.62( \pm 2.00)$ \\
Right femoral neck BMD & $-2.43( \pm 0.91)$ & $-2.53( \pm 1.48)$ \\
$\quad$ z-score
\end{tabular}

*There are no significant differences at the $p=0.05$ level.

Table 2

Familial versus nonfamilial cases*

\begin{tabular}{lcc}
\hline Parameter & $\begin{array}{c}\text { Familial Cases } \\
(\mathrm{n}=31)\end{array}$ & $\begin{array}{c}\text { Nonfamilial } \\
\text { Cases }(\mathrm{n}=38)\end{array}$ \\
\hline Mean age in years (range) & $62(37,8 \mathrm{I})$ & $64(36,86)$ \\
Mean age at diagnosis in years (range) & $57(32,77)$ & $59(29,81)$ \\
Percent female & 87 & 79 \\
Percent with fracture $>$ 50 years old & $25(7 / 28)$ & $20(7 / 35)$ \\
Mean pedigree size (\# relatives) & 17.4 & 16.1 \\
Lumbar BMD z-score & $-2.24( \pm 1.48)$ & $-2.54( \pm 1.18)$ \\
Right femoral neck BMD z-score & $-2.27( \pm 1.04)$ & $-2.60( \pm 1.32)$ \\
Mean age at fracture & 59 & 63 \\
\hline
\end{tabular}

*There are no significant differences at the $p=0.05$ level.

Table 3

Empiric risk estimates for osteoporosis

\begin{tabular}{lcc}
\hline $\begin{array}{l}\text { Relative Type } \\
\text { (No. Female/Male) }\end{array}$ & $\begin{array}{c}\text { \% Risk to } \\
\text { Females (no.) }\end{array}$ & $\begin{array}{c}\text { \% Risk to } \\
\text { Males (no.) }\end{array}$ \\
\hline Parents (69/69) & $33(23)$ & $6(4)$ \\
Siblings (75/79) & $19(10)$ & $3(2)$ \\
Offspring (70/59) & $0(0)$ & $0(0)$ \\
Grandparents (138/138) & $6(8)$ & $1(2)$ \\
Aunts/uncles (232/240) & $6(15)$ & $1(3)$ \\
\hline
\end{tabular}

\section{DISCUSSION}

Forty-five percent of probands reported a family history of osteoporosis. There were no significant demographic or phenotypic differences between familial and nonfamilial cases. Although we did not verify family history reports, accuracy of family history reports for other common, chronic disorders is relatively high. ${ }^{42.43}$ Furthermore, self-reports of hip, wrist, and humerus, fractures are known to be reasonably accurate. ${ }^{44}$

This included age, age at osteoporosis diagnosis, gender proportion, proportion with osteoporosis-related fracture, mean pedigree size, and BMD z-scores at both the lumbar and right femoral neck regions. The observation that familial cases did not significantly differ from nonfamilial cases appears to violate a tenet of common disease genetics, as it is often claimed that in most common diseases with a genetic component, individuals with a positive family history tend to have more severe phenotype and earlier age of onset or diagnosis.

Overwhelming evidence such as that derived from twin and population studies exists verifying a genetic contribution to the etiology of osteoporosis. Our finding of a lack of differences between familial and nonfamilial osteoporosis cases might appear incongruous with this knowledge. However, there is precedence for this concept, as type I diabetes with and without family history is phenotypically similar and both have strong associations with HLA class II. ${ }^{45}$

In our investigation, the group at greatest risk for osteoporosis were female relatives, with an empiric risk as high as $33 \%$ for mothers. This risk is not significantly different from the estimated population risk of approximately $30 \%$ for postmenopausal Caucasian women. ${ }^{1}$ Both aunts and grandmothers had empiric risks of $6 \%$. Since we would expect these women to have at least the population's risk, the risk estimates for second degree relatives may well be underestimates due to underreporting. In male relatives, a similar trend was observed with fathers having an empiric risk six times greater than uncles and grandfathers. In siblings and offspring, the empiric risks are likewise probable underestimates because of nonpenetrance in this disease of later onset. Relevant age-specific incidence data for osteoporosis are not available. This prohibits age-adjustment, which could provide more accurate empiric risk estimation for these younger relatives.

Our data suggest that for clinical risk assessment and prevention strategy planning, in general, the family history does not appear to substantially alter or impact the risk stratification of a consultand presenting with a family history of osteoporosis. However, this does not obviate the need for documenting reports of osteoporosis in the family, particularly since there are some rare single gene disorders that feature osteoporosis and the family history may reveal such a diagnosis. These results also suggest that identification of osteoporosis genes might be as amenable to population association studies as compared with family-based linkage analysis. Once osteoporosis genes are identified, population-based screening in high risk ethnic groups may be more appropriate than family-based screening.

\section{References}

1. Melton LJ III. How many women have osteoporosis now? J Bone Miner Res 1995; 10:175-177.

2. Peck WA. Consensus development conference: diagnosis, prophylaxis, and treatment of osteoporosis. Am J Mcd 1993;94.

3. Kelsey IL. Osteoporosis: prevalence and incidence in osteoporosis. Proceedings of the NIH Consensus Development Conference. Bethesda, MD, April 2-4, 1984:2528.

4. National Osteoporosis Foundation. Osteoporosis: physician's guide to prevention and treatment of osteoporosis. Belle Mead: Excerpta Medica, Inc., 1999.

5. Riggs BL, Wahner HW, Seeman E, Offord KP, Dunn WL, Mazess RB, Johnson KA, Melton $\mathrm{Ll}$. Changes in bone mineral density of the proximal femur and spine with aging: differences between postmenopausal and senile osteoporosis syndromes. J Clin lnvest 1982;70:716-723. 
6. Alffram PA, Bauer $\mathrm{CH}$. Epidemiology of fractures of the forearm: a biomechanical investigation of bone strength. J Bone Joint Surg Am 1962:44:105-114.

7. Firooznia H, Golimbu C, Rafii M, Schwartz MS, Alterman ER. Quantitative computed tomography assessment of spinal trabecular bone. II. In osteoporotic women with and without vertebral fractures. J Comput Tomogr 1984;8:99-103.

8. Silverman SL. The clinical consequences of vertebral compression fracture. Bone 1992;13:527-531.

9. World Health Organization. Assessment of fracture risk and its application to screening for postmenopausal osteoporosis: WHO Technical Report Series. Geneva: World Health Organization, 1994.

10. Looker AC, Orwoll ES, Johnston CC, Lindsay RL, Wahner HW, Dunn WL, Calvo MS, Harris TB, Heyse SP. Prevalence of low femoral bone density in older U.S. adults from NHANES III. J Bone Miner Res 1997;12:1761-1768.

11. Sowers M, Randolph JF, Crutchfield M, Jannausch ML, Shapiro B, Zhang B, La Pietra M. Urinary ovarian and gonadotropin hormone levels in premenopausal women with low bone. J Bone Miner Res 1998;13:1191-1202.

12. Adachi ID. Corticosteroid-induced osteoporosis. Am J Med Sci 1997;313:41-49.

13. Krane SM, Holick MF. Metabolic bone disease. In: Fauci AS, Braunwald EB, Isselbacher KJ, editors. Harrison's principles of internal medicine. New York: McGrawHill, 1993;2247-2253.

14. Nguyen TV, Sambrook PN, Eisman JA. Bone loss, physical activity, and weight change in elderly women: the Dubbo osteoporosis epidemiology study. J Bone Miner Res 1998;13:1458-1467.

15. Stewart AF, Adler M, Byers CM, Sergre GV, Broadus AE. Calcium homeostasis in immobilization: an example of resorptive hypercalcinuria. N Engl J Med 1982;306: $1136-1140$.

16. Spencer H, Kramer L. NIH Consensus Conference: Osteoporosis: factors contributing to osteoporosis. Nutrition 1986;116:316-319.

17. Heaney RP, Matkovic V. Inadequate peak bone mass. In: Riggs BL, Melton IL III, editors. Osteoporosis: etiology, diagnosis, and management. Philadelphia: Lippincott-Raven Publishers, 1995;115-131.

18. Spencer $H$, Rubio N, Rubio E, Indreika $M$, Seitam A. Chronic alcoholism: frequently overlooked cause of osteoporosis in men. Am J Med 1986;80:393-397.

19. Jacobson SJ, Cooper C, Gottlieb MS, Goldberg J, Yanke DP, Melton LI III. Hospitalization with vertebral fracture among the aged: a national population-based study. Epidemiology 1992;3:515-518.

20. Horton WA. Connective tissue biology and common skeletal disorders. In: King RA, Rotter JI, Motulsky AG, editors. The genetic basis of common diseases. New York: Oxford University Press, 1992;625-640.

21. $\mathrm{OMIM}^{\mathrm{Tn}}$ : Online Mendelian Inheritance in Man, National Center for Biotechnology Information, Bethesda, Maryland. 1999. www3.ncbi.nlm.nih.gov/Omim

22. $\mathrm{OMIM}^{\mathrm{nw}}$ : Online Mendelian Inheritance in Man, National Center for Biotechnology Information, Bethesda, Maryland. 1999. www3.ncbi.nlm.nih.gov/htbin-post/ Omim/getmim.

23. Evans RA, Marel GM, Lancaster EK, Kos S, Evans M, Wong SY. Bone mass is low in relatives of osteoporotic patients. Ann Intern Med 1998;109:870-873.

24. Curmings SR, Nevitt MC, Browner WS, Stone KS, Fox KM, Ensurd KE, Cauley J, Black D, Vogt TM. Risk factor for hip fracture in white women. $N$ Engl J Med 1995;332:767-773.

25. Pocock NA, Eisman JA, Hopper JL, Yeates MG, Sambrook PN, Eberl S. Genetics determinants of bone mass in adults: a twin study. J Clin Invest 1987;80:706-710.

26. Dequeker J, Nijs J, Verstraeten A, Geusens P, Gevers G. Genetic determinants of bone mineral content at the spine and radius: a twin study. Bone 1987:8:207-209.

27. Smith DM, Nance WE, Kang KW, Christian JC, Johnston CC Ir. Genetic factors in determining bone mass. J Clin Invest 1973;52:2800-2808.

28. Christian IC, Yu P-L, Slameda CW, Johnston CC Jr. Heritability of bone mass: a longitudinal study in aging male twins. Am J Hum Genet 1989;44:429-433.

29. Krall EA, Dawson-Hughes $B$. Heritable and life determinants of bone mineral density. J Bone Miner Res 1993;8:1-9.

30. Morrison N, Qi JC, Tokita A, Kelley PI, Crofts L, Nguyen TV, Sambrook PN, Eisman JA. Prediction of bone density from vitamin D receptor alleles. Nature 1994;367: $284-287$.

31. Sainz J, Van Tornout JM, Loro ML, Sayre J, Roe TF, Gilsanz V. Vitamin D-receptor gene polymorphisms and bone density in prepubertal American girls of Mexican descent. N Engl J Med 1997;337:77-82.

32. Gennari L, Becherini L, Masi L, Mansani R, Gonnellil S, Cepollaro C, Martini S, Montagnani A, Lentini G, Becorpi AM, Brandi ML. Vitamin D and estrogen receptor allelic variants in Italian postmenopausal women: evidence of multiple gene contribution to bone mineral density. J Clin Endocrinol Metab 1998;83:939-944.

33. Feskanich D, Hunter DJ, Willett WC, Hankinson SE, Hollis BW, Hough HL, Kelsey KT, Colditz GA. Vitamin D receptor genotype and the risk of bone fractures in women. Epidemiology 1998;9:535-539.

34. Hustmyer FG, Peakcock M, Hui S, Johnston CC, Christian J. Bone mineral density in relation to polymorphism at the vitamin $\mathrm{D}$ receptor gene locus. $J$ Clin Invest $1994 ; 94: 2130-2134$.

35. Lim SK, Park YS, Park JM, Song YD, Lee EJ, Kim KR, Lee HC, Huh KB. Lack of association between vitamin $\mathrm{D}$ receptor genotypes and osteoporosis in Koreans. $J$ Clin Endocrinol Metab 1995;80:3677-3681.

36. Houston LA, Grant SFA, Reid DM, Ralston SH. Vitamin D receptor polymorphism, bone mineral density, and osteoporotic vertebral fracture: studies in a UK population. Bone 1996;18:249-252.

37. Garnero P, Borel O, Sornay-Rendu E, Arlot ME, Delmas PD. Vitamin D receptor polymorphisms are not related to bone turnover, rate of bone loss, and bone mass in postmenopausal women: the OFELY study. J Bone Miner Res 1996;1 1:827-834.

38. Looney JE, Yoon HK, Fischer M, Farley SM, Wergedal JE, Baylink DI. Lack of high prevalence of the BB vitamin D receptor genotype in severely osteoporotic women. $J$ Clin Endocrinol Metab 1995;80:2158-2162.

39. Grant SFA, Reid DM, Blake G, Herd R, Fogelman I, Ralston SH. Reduced bone density and osteoporosis associated with a polymorphic Spl binding site in the collagen type 1-alpha 1 gene. Nature Genet 1996;14:203-205.

40. Uitterlinden AG, Burger $\mathrm{H}$, Huang Q, Yue F, McGuigan FE, Grant SF, Hofman A van Leeuwen IP, Pols HA, Ralston SH. Relation of the collagen type I-alpha I gene to bone density and the risk of osteoporotic fractures in postmenopausal women. N Engl J Med 1998:338:1016-1021.

41. Spotila LD, Costantinou CD, Sereda L, Ganguly A, Riggs BL, Prockop DJ. Mutation in a gene for type I procollagen (COLIA2) in a woman with postmenopausal osteoporosis: evidence for phenotypic and genotypic overlap with mild osteogenesis imperfecta. Proc Nat Acad Sci U S A 1991;88:5423-5427.

42. Kee F, Tiret L, Robo IY. Reliability of reported family history of myocardial infarction. BMJ 1993;307:1528-1530.

43. Love RR, Evans AM, Josten DM. The accuracy of patient reports of a family history of cancer. I Chronic Dis 1985;38:289-293.

44. Nevitt MC, Cummings SR, Browner WS, Seeley DG, Cauley JA, Vogt TM, Black $D M$. The accuracy of self-report of fractures in elderly women: evidence from a prospective study. A in J Epidemiol 1992;135:490 - 499

45. Rotter JI, Vadheim CM, Rimoin DL. Diabetes mellitus. In: King RA, Rotter II, Motuslky AG, editors. The genetic basis of common diseases. New York: Oxford University Press, 1992; 413-464. 